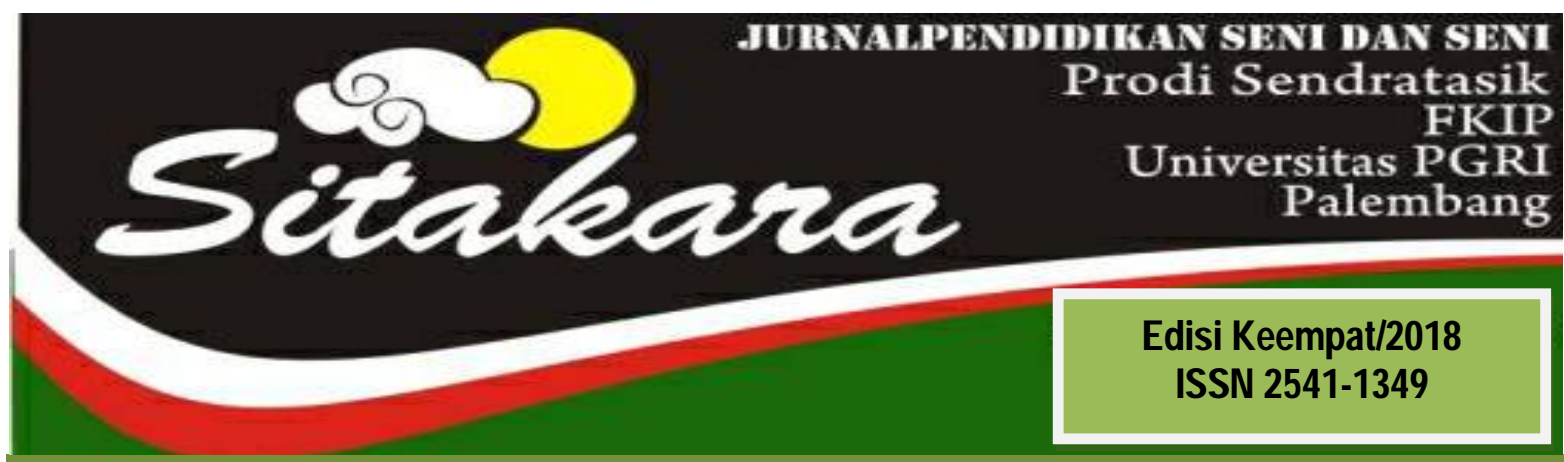

Objektifitas Imajinatif Dalam Pertunjukan Teater

Mohammad A rfani

Makna Estetis Dalam Simbol Tatto

Novdaly Fillamenta

Desain A tas (Air D esign) D alam Dimensi Estetik Pertunjukan Karya Tari

Efita Elvandari

Pengaruh M etode D emonstrasi D alam Pembelajaran Tari Burung Bermain

Pada Kegiatan Ekstrakurikuler D i SM P N egeri 36 Palembang

Ria Moulina A driamul

Gerak: Perjalanan D ari M otif Ke Komposisi Tari

Rully Rochayati

Sastra Lisan Dalam Kesenian Saluang D endang Sumatera Barat

Nofroza Yelli

Rangsang A udio Sebagai M otivasi Pada Penciptaan Karya

Tari Tunggu Tubang Dalam Pembelajaran Koreografi di Universitas

PG RI Palembang

Treny Hera

M otif Bungo Pacik Pada Tenunan Songket Palembang

Mainur

Konsep Kreatifitas Wallas D alam Proses Penciptaan Tari Tepak Keraton

Nurdin

A nalisis Bentuk Gerak Tari Turak Di Sanggar Studio Lingga

Kota Lubuklinggau

Sisca Fitriani

Bentuk Figur Tokoh Wayang Kulit Palembang

Robert Budi Laksana 


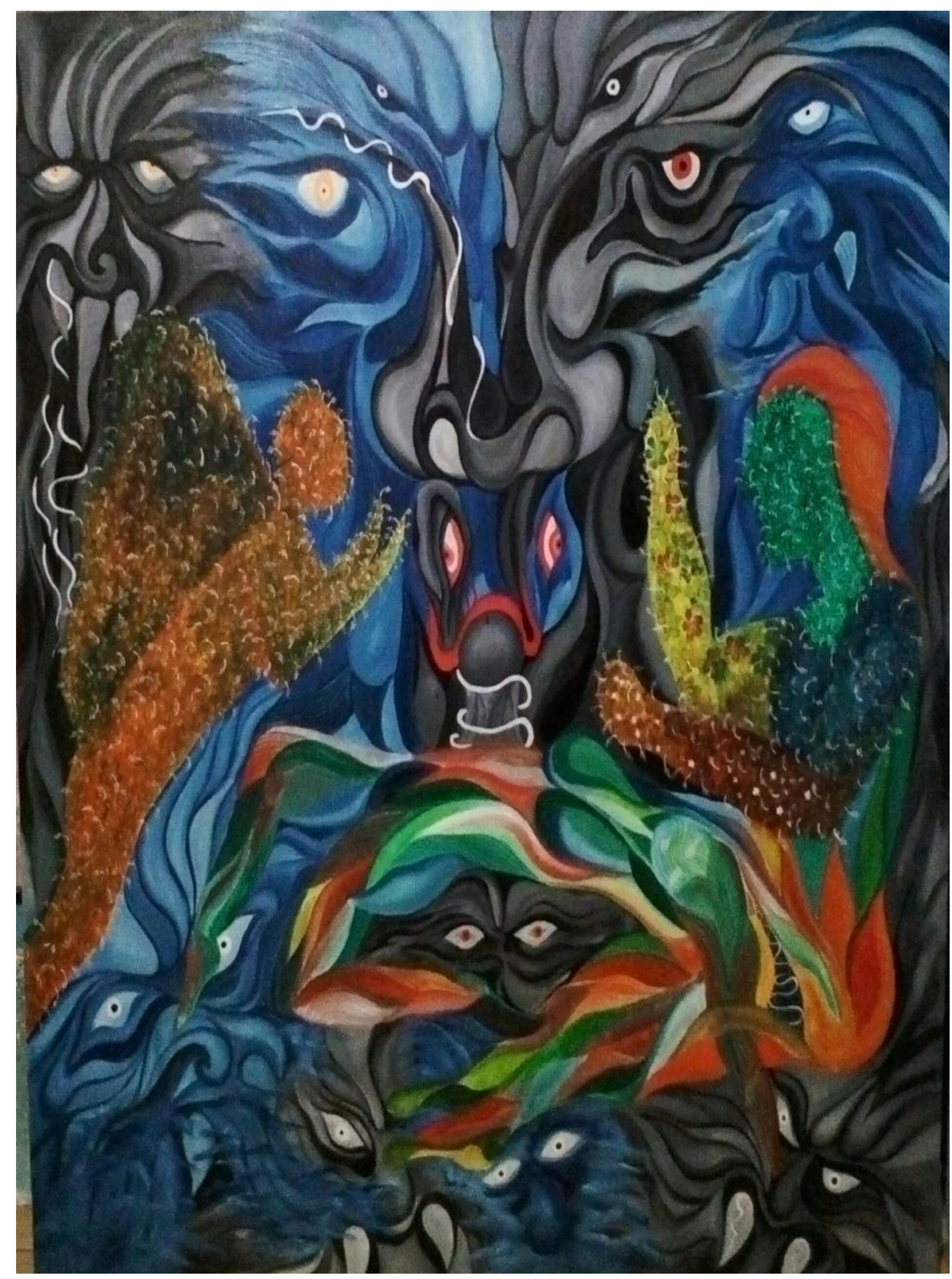




\section{SITAKARA}

\section{JURNAL PENDIDIKAN SENI DAN SENI BUDAYA}

Edisi 4, Februari 2018

\section{DEWAN REDAKSI}

1. PenanggungJawab

2. KetuaDewan Redaksi

3. WakilDewanRedaksi

4. Sekretaris

5. PenyuntingPelaksana

6. Penyunting Ahli

7. Setting
:

: Dra. Andinasari, M.M., M.Pd.

: RullyRochayati, M.Sn

: Nofroza Yelli, M.Sn

: Treny Hera, S.Pd., M.Sn

: 1. Efita Elvandari, M.Sn

2. Arfani, S.Pd., M.Sn

: 1. Prof. Dr. Triyono Bramantyo, P.Hd (ISI Yogyakarta)

2. Dr. DessyWardiah, M.Pd (UPGRI)

3. Dr. Slamet, M.Hum (ISI Surakarta)

4. Yayan Hariyansyah, M.Sn (UIGM)

: 1. Mainur, S.Pd.,M.Sn

2. I Komang Kerta Yana, S.Si

\section{AlamatRedaksi}

Program StudiPendidikanSendratasik JurusanPendidikanKesenian FKIP Universitas PGRI Palembang Jl. A. YaniLorongGotongRoyong 9/10 Ulu Palembang Telp. 0711-510043 Fax. 0711-514782 E-mail: jurnalsitakarasendratasik@yahoo.com 


\section{DAFTAR ISI}

Objektifitas Imajinatif D alam Pertunjukan Teater

M ohammad A rfani

Makna Estetis D alam Simbol Tatto

Novdaly Fillamenta

D esain A tas (Air D esign) D alam D imensi Estetik Pertunjukan Karya Tari

Efita Elvandari

Pengaruh M etode D emonstrasi D alam Pembelajaran Tari Burung Bermain 25 Pada Kegiatan Ekstrakurikuler Di SM P N egeri 36 Palembang

Ria M oulina Adriamul

G erak: Perjalanan D ari M otif Ke Komposisi Tari

Rully Rochayati

SastraL isanD al amK esenianSaluangD endang Sumatera Barat

N ofroza Yelli

Rangsang Audio Sebagai M otivasi Pada Penciptaan Karya

Tari Tunggu Tubang Dalam Pembelajaran Koreografi di Universitas

PG RI Palembang

Treny Hera

Motif Bungo Pacik Pada Tenunan Songket Palembang

Mainur

Konsep K reatifitas Wallas D alam Proses Penciptaan Tari Tepak Keraton N urdin

Analisis Bentuk G erak Tari Turak Di Sanggar Studio Lingga

Kota Lubuklinggau

Sisca Fitriani

BentukFigurT okohWayangKulit Palembang 


\title{
KONSEP KREATIFITAS WALLAS DALAM PROSES PENCIPTAAN TARI TEPAK KERATON
}

\author{
Oleh : \\ Nurdin \\ (Program Studi Sendratasik FKIP Universitas PGRI Palembang)
}

\section{Konsep Kreatifitas Wallas dalam Proses Penciptaan Tari Tepak Keraton}

\begin{abstract}
ABSTRAK
Tari Tepak Keraton merupakan salah satu tari sambut yang terdapat di Kota Palembang Provinsi Sumatera Selatan. Keberadaan tari ini tidak terlepas dari peran Anna Kumari sebagai penciptanya. Sebagai seorang penata tari beliau tentunya memiliki ide kreatif yang menunjang hingga mampu menciptakan sebuah karya tari yang bernilai klasik. Penelitian ini akan mengungkap persoalan latar belakang yang mendorong Anna Kumari menciptakan karya tari ini dan hubungan sebuah konsep kreativitas terhadap proses penciptaannya. Dalam penelitian ini digunakan metode deskriptif analisis kualitatif. Hasil penelitian ini mengungkapkan bahwa tari ini diciptakan pada tahun 1967, hal ini dilatarbelakangi pada tahun tersebut, tari Gending Sriwijaya yang pada saat itu dilarang dipertunjukkan karena disinyalir ada hubungan dengan G30S/PKI. Maka dimintalah Anna Kumari sebagai penata tari muda pada saat itu untuk menciptakan sebuah tari sambut baru untuk menyambut kedatangan Pangdam II Sriwijaya yang akan datang ke Kota Palembang untuk bertugas. Proses penciptaannya memiliki beberapa tahapan yang dilakukan yaitu persiapan, inkubasi, pencerahan, dan pelaksanaan yang sesuai dengan konsep Wallas.
\end{abstract}

Kata Kunci : Tari Tepak Keraton, Kreativitas.

\section{A. Pendahuluan}

Tari Tepak Keraton adalah tari penyambutan yang terdapat di Kota Palembang, merupakan satu dari sekian banyak tari yang mewarnai acara seremonial di Kota Palembang. Jika ditilik dari perspektif sosial religi, Kota Palembang merupakan kota penganut agama Islam yang besar dan kuat, terbukti dari adanya Kesultanan Palembang Darussalam yang menandakan kerajaan dan pemerintahan Islam pernah memerintah Kota Palembang jauh sebelumnya. Tari Tepak Keraton memiliki hubungan yang erat dengan kebaradaan Kesultanan Palembang

Darussalam hingga saat ini.

Didapat informasi dari wawancara yang dilakukan pada November 2015, salah satu dari seniman Kota Palembang yang terus melestarikan tari Tepak Keraton, yaitu Mirza Indah Dewi putri dari Anna Kumari, tari Tepak Keraton Berfungsi sebagai tari penyambutan tamu kehormatan. dalam proses penyambutannya, tari Tepak Keraton Palembang ditarikan oleh 7 orang penari 1 orang pesilat, dan 1 orang pemegang payung dan 2 orang pemegang tombak. Senada dengan tari sambut yang ada di Sumatera Selatan selain ditarikan dengan jumlah penari 
yang ganjil, tari ini dilengkapi pula dengan penyuguhan tepak ${ }^{1}$ sesuai dengan nama tarinya. Di dalam tepak yang disuguhkan kepada tamu kehormatan terdapat lima cupu²yang masing-masing berisikan daun sirih, pinang, kapur, getah gambir dan tembakau. kelima sajian yang terdapat di dalam tepak tersebut diramu menjadi satu untuk disuguhkan kepada tamu agung, yang dikenal dengan nama sekapur sirih. Sekapur sirih merupakan inti dari hampir seluruh tarian sambut yang terdapat di pulau Sumatera.

Berdasarkan wawancara dengan Anna Kumari pada November 2016, beliau memaparkan bahwa tari Tepak Keraton berbeda dengan tari Tanggai dan tari Gending Sriwijaya yang terdapat di Kota Palembang yang dipengaruhi unsur agama Hindu dan Budha. Tari Tepak Keraton lebih dipengaruhi agama Islam dan kebudayaan Melayu, sehingga tergambar dari gerak, tata rias busana dan musik iringannya yang mencirikan kebudayaan Melayu.

Proses penciptaan tari Tepak Keraton dapat dikaji menggunakan kaidah-kaidah penciptaan di dalam ilmu tari. Terciptanya tari Tepak Keraton yang memiliki ciri penyajian yang khusus dari tari sambut sebelumnya yang

${ }^{1}$ Tepak merupakan kotak kecil yang berisikan sekapur sirih yang digunakan untuk menyambut tamu kehormatan pada setiap tari sambut di Sumatera Selatan pada umumnya.

${ }^{2}$ Cupu merupakan wadah-wadah kecil di dalam tepak, yang berisikan daun sirih, getah gaambir, tembakau, pinang dan kapur. pernah ada memberikan pemikiran dan asumsi dasar untuk diteliti terkait kreativitas Anna Kumari sebagai pencipta tari Tepak Keraton.

Berdasarkan wawancara dengan Anna Kumari, November 2016, tari Tepak Keraton lahir pada tahun 1966, untuk penyambutan tamu agung Bapak Brigjen Ishak Juarsa selaku Panglima Kodam IV Sriwijaya. Dimintalah seorang penata tari muda pada waktu itu Anna, Untuk menciptakan sebuah tari sambut yang tidak menyerupai tari sambut sebelumnya yang pernah ada yaitu tari Gending Sriwijaya, Karena disnyalir pencipta lirik lagu Gending Sriwijaya yang digunakan sebagai musik pengiringnya terlibat dalam organisasi PKI (Partai Komunis Indonesia). Dengan mengangkat konsep keislaman namun tanpa meninggalkan unsur-unsur ketradisian yang berlaku, maka teciptalah sebuah tari sambut baru yang kemudian dikenal dengan nama tari Tepak Keraton.

Dari sejak awal lahirnya tari Tepak Keraton hingga saat ini, belum mengalami perubahan dalam segi koreografi dan musiknya, namun dalam segi tata rias busana serta pola lantainya dapat menyesuaikan situasi dan kondisi pada saat penyajiannya.

Tari Tepak Keraton mampu bertahan lebih kurang selama 50 tahun sebagai tari sambut di Kota Palembang merupakan sebuah usaha dan perjuangan yang besar dari Anna sebagai penciptanya, bagaimana tidak demi untuk menjaga kemurnian tari ini Anna harus meminta sumpah kepada semua penari yang 
akan diajarkan tarian ini untuk tidak menyebar luaskan dan mengajarkan serta menampilkan tarian ini tanpa ada persetujuan dan atau membawa nama sanggar Anna Kumari (wawancara Anna Kumari, November 2016).

Dengan upaya itu terbukti sampai saat ini tidak ada sanggar selain sanggar Anna Kumari yang memiliki tari Tepak Keraton di Kota Palembang. Keunikan lain dari tari ini adalah terletak pada sajian bentuk koreografi yang dikemas dalam bentuk silat yang dilakukan oleh seorang penari perempuan. Keunikan silat dalam tarian ini yaitu penari silat perempuan tersebut harus dari keturunan Kesultanan Palembang Darussalam, dari keharusan ini kemudian menjadi penghambat bagi tari Tepak Keraton untuk dilestarikan selain oleh sanggar Anna Kumari.

Anna merupakan seorang koreografer dan maestro tari tradisi di Sumatera Selatan khususnya di Kota Palembang. Terlahir sebagai dara Palembang, di Palembang 10 November 1945. Kesenimanan dan kreativitas Anna Kumari di dalam berkesenian mendapat respon positif dari berbagai kalangan, mulai dari budayawan, seniman, elit birokrat serta masyarakat pendukung kebuayaan.

Hal ini terbukti dari sederet prestasi dan penghargaan yang telah ia raih sebagai seorang seniman dan pelestari kebudayaan khususnya di bidang tari di antaranya yaitu: pada tahun 1972 mendapat penghargaan dari Pangdam IV Sriwijaya, pengghargaan direktorat pengembangan kesenian Jakarta tahun 1980, penghargaan dari Presiden Republik Indonesia tahun 1993, California Gift Show Los Angeles USA tahun1998, Anugerah Citra Wanita Pembangunan Indonesia di tahun 2004 dan tahun 2015 mendapat anugerah kebudayaan dari Kementrian Pendidikan dan Kebudayaan dengan kategoriPelestari Kebudayaan. Hingga saat ini seorang Anna Kumari tetap mengukir prestasi dalam kesenimanannya.

Karya tari yang pernah diciptakan oleh Anna di antaranya: tari Selendang Mayang, tari Gades Tepian Musi, tari Tenun Songket, tari Ragam Perca, tari Elang Terbang, tari Dewi Samudra, tari Cek Engkleng, dan tari Kumpe Berayun. Dari sebagian kecil contoh karya tari ciptaannya ini, maka dapat dikatakan bahwa Anna merupakan seorang koreografer yang kreatif pada masanya.

Hal yang menjadi asumsi dalam penelitian kajian ini yaitu kreativitas seorang Anna Kumari dalam berproses menciptakan sebuah karya tari sambut tradisi yang mampu bertahan hingga saat ini. Kreativitas tersebut akan dianalisis dengan menggunakan konsep kreativitas Wallas yang menyebutkan bahwa ada empat tahapan dalam kreativitas yaitu meliputi tahap persiapan, inkubasi, pencerahan, dan pelaksanaan. Dengan demikian dari latar belakang di atas dapat diangkat sebuah perspektif kajian dengan judul "konsep kreativitas Wallas dalam proses penciptaan Tari Tepak Keraton". 


\section{B. METODE PENELITIAN}

Penelitian ini bersifat deskriptif analisis kualitatif, tujuannya adalah mendeskripsikan bagaimana kreativitas dari seorang Anna Kumari dalam memciptakan tari Tepak Keraton ditinjau dari konsep kreativitas Wallas. Sesuai dengan bidang keahlian yang dimiliki yaitu tari, maka objek formal dan material dalam penelitian ini difokuskan pada ilmu tari, dengan menggunakan pendekatan etnografi tari, yaitu menjelaskan tentang tari serta elemen-elemen yang melingkupinya.

Penelitian model ini dapat dikatakan sebagai bentuk penelitian etnokoreologi, yang lebih menekankan pada tari sebagai subyek dan gender tari sebagai objeknya.

1. Lokasi Penelitian

Penelitian ini dilaksanakan di Kota Palembang Provinsi Sumatera Selatan tepatnya di sanggar Anna Kumari Palembang.

2. Sumber Data

Sumber data dalam penelitian ini adalah sumber data primer yaitu manusia dan tingkahlakunya. Sumber data sekunder yang digunakan berupa dokumen, arsip, rekaman dan foto-foto.

3. Teknik Pengumpulan Data

Teknik pengumpulan data dalam penelitian ini meliputi observasi, wawancara, dan studi pustaka.
Kegiatan observasi tidak dapat terpenuhi hanya dengan kegiatan melihat atau menonton serta mendengar saja. Keterlibatan peneliti secara langsung dengan objek penelitian serta subjek sebagai sumber otentik perlu dilakukan, dengan kata lain dalam kajian etnografi, keterlibatan secara utuh sangat dibutuhkan dan menjadi syarat utama bagi peneliti agar mampu melebur dan bersinergi dengan objek kajian, observasi tipikal ini biasa dikenal dengan partisipant observer (observasi terlibat secara langsung).

Hal yang pertama kali dilakukan dalam observasi ini yaitu menetapkan informan, dari informan ini akan membuka fenomena budaya yang lebih transparans hingga dapat dijadikan peneliti sebagai objek kajian dan pokok permasalahan. Dengan bantuan informan ini juga peneliti dapat dengan mudah menyelami dan memahami fenomena budaya yang ada pada saat ini. Namun demikian observasi tidak langsung pun tetap dilakukan peneliti sebagai penyeimbang data.

Dikarenakan penelitian ini lebih memfokuskan pada kesenimanan informan, maka wawancara yang dilakukan tidak bersifat kaku. Proses wawancara dilakukan dengan menjalin hubungan harmonis untuk dapat menggali informasi kedirian dari informan.

Melalui studi pustaka dan studi lapangan. Data dikumpulkan dengan cara membaca dan menulis hal-hal penting yang berhubungan dengan masalah, dilakukan secara berkesinambungan dan terus menerus 
guna memfokuskan penelitian, menentukan teknik pengumpulan data guna memperoleh sumber yang bermanfaat bagi penelitian.

Studi pustaka yang dilakukan bersumber dari buku tari Tepak Keraton Dinas Kebudayaan dan Pariwisata Kota Palembang, dan beberapa buku mengenai kreativitas antara lain, Cara Cerdas Melejitkan IQ Kreatif Anak, dan Kreativitas Bagaimana Menanam, Membangun dan Mengembangkannya.

Dokumen dan arsip, keduanya merupakan hasil rekaman pertunjukan tari Tepak Keraton dari sanggar Anna Kumari di Kota Palembang dan koleksi Dinas Kebudayaan dan Pariwisata Kota Palembang dijadikan data pendukung dalam penelitian.

Proses analisis data dilakukan dari sejak awal perlu segera digarap dan dipilahpilah bersamaan dengan proses pengumpulan data, sehingga analisis data dapat berlangsung secara terus menerus dan berkesinambungan. (Arikunto, 2010 : 278). Menurut Sugiyono (2009:61), analisis sudah mulai dilakukan sejak merumuskan dan menjelaskan masalah di awal penelitian, dengan kata lain dilakukan sebelum terjun ke lapangan dan terus menerus sampai penulisan hasil penelitian, data yang diperoleh dari penelitian ini merupakan data kualitatif yang merupakan data observasi yang berbasis tugas kemudian dikategorikan hingga didapat data deskripsi tentang konsep kreativitas pada penciptaan tari Tepak Keraton oleh Anna Kumari.
Jadi metode yang digunakan dalam penulisan ini adalah metode deskriptif analisis yaitu penelitian yang digunakan untuk menganalisis data dengan cara mendeskripsikan atau menggambarkan data yang berlaku secara umum dan generalisasi (Sugiyono,2010:14) Kemudian tipe penelitian yang digunakan adalah kualitatif dengan mengumpulkan data-data berupa dokumen, mengobservasi langsung, menelaah kajiankajian pustaka yang dideskripsikan dalam bentuk kata-kata.

Pada dasarnya keterampilan dan kreativitas merupakan sebuah konsep, dan aksi sebagai wujud ide kreatif, kemudian akan menghasilkan bentuk yang utuh pada akhirnya, hal ini senada dengan pemikiran Sumardjo.

"Kreativitas adalah suatu kondisi, suatu sikap atau keadaan mental yang sanat khusus sifatnyadan hampir tidak mungkin dirumuskan. Manusia kreatif adalah manusia yang memilii kemampuan kreatif, antara lain kesigapan menghasilkan gagasan baru, yang baru muncul jika seseorang telah mengenal secara jelas yang telah ada dan tersedia dalam lingkungan hidupnya. Gagasan kreatif umumnya adalah gagasan asli, otentik, unik, milik dirinya, gagasan ini berbeda dan lain dari gagasan yang telah ada" (Sumardjo, 2000: 83).

Dalam berproses kreatif Anna melakukan beberapa tahapan agar mampu menghasilkan karya yang dapat diakui masyarakat, tahapan-tahapan tersebut dapat dikaji melalui konsep kreativitas Wallas dalam 
Andrianto, (2012: 105) yang mengemukakan ada empat tahap dalam proses kreatif yang harus dijalani oleh penggagas yaitu, persiapan, (preparation), inkubasi (incubation), pencerahan, dan tahap pelaksanaan. Konsep ini digunakan sebagai pisau bedah untuk menjawab tentang tahapan kreativitas Anna Kumari dalam menciptakan tari Tepak Keraton.

\section{PEMBAHASAN}

Tari Tepak Keraton diciptakan oleh Anna Kumari melalui sebuah proses kreatif dalam tahapan-tahapan tertentu. Proses kreatif mensyaratkan kreativitas sebagai dasar. Dari pendapat Munandar (2009: 12) kreativitas sebagai hasil interaksi antara individu dan lingkungannya, kemampuan untuk membuat kombinasi baru, berdasarkan data, informasi,atau unsur-unsur yang sudah ada atau dikenal sebelumnya, yaitu semua pengalaman dan pengetahuan yang telah diperoleh seseorang selama hidupnya baik itu dilingkungan sekolah, keluarga dan masyarakat.

Anna menciptakan tari Tepak Keraton dengan bentuk tari penyambutan tamu agung di Kota Palembang. Dengan kepenarian, kesenimanan serta pemahamannya terhadap tari sambut dan tradisi di Kota Palembang, Anna memulai ide kreatifnya yang muncul ketika menyikapi fenomena yang yang terjadi pada saat itu dan memperhatikan akan keberadaan dan perkembangan seni tradisi setempat.

Orang yang kreatif biasanya menetapkan ciri khas dalam memulai karyanya, Anna memiliki ciri khas tersendiri dalam menata gerak, salah satunya pada ragam gerak Nyaturi- maju dan Mundur, dengan posisi badan yang agak sedikit merendah, memiliki arti bahwa masyarakat Kota Palembang bersikap ramah dan menghaturkan kepada setiap tamu yang datang.

Proses kreativitas umumnya akan berkualitas jika dalam proses tersebut terjadi integrasi dari beberapa tahapan proses tersebut, artinya dari awal mulainya proses kreativitas berlangsung tetap berkesinambungan atau tidak berhenti sampai tahap pembuktian, yaitu terciptanya suatu karya. Wallas menyebutkan empat tahapan dalam kreativitas meliputi tahap persiapan, inkubasi, pencerahan, dan pelaksanaan.

1. Tahap Persiapan

Dalam tahapan ini koreografer menghimpun keahlian dalam bidang khusus seputar permasalahan yang dikaji dengan jalan mengumpulkan sebanyak mungkin fakta dari fenomena yang sedang terjadi pada saat itu. Pada tahapan ini Anna mempelajari dan memperhatikan dari pada bentuk dan karakteristik tari sambut yang terdapat di Kota Palembang dan di Sumatera Selatan pada umumnya. 
Dimulai dari teknik gerak, struktur penyajian, hingga tata rias dan busana dari tari sambut di Kota Palembang. Selain itu Anna banyak membaca guna mengumpulkan fakta, ide, opini mengenai fenomena yang akan diselami. Setelah semua data terkumpul Anna melakukan pengolahan konsep garapan yang merupakan bahan-bahan pemikiran untuk menghasilkan konsep dan karya yang baru.

Proses kreatif Anna dimulai dengan adanya permintaan untuk membuat tari penyambutan yang baru dalam acara penyambutan kedatangan Panglima Kodam IV Sriwijaya yang akan bertugas di Kota Palembang. Sebagai panglima tertinggi yang memimpin Kodam IV Sriwijaya pada saat itu kedatangannya yang pertama kali merupakan sesuatu yang sangat dinantikan dan dianggap sebagai tamu agung yang patut disambut dengan meriah. Atas perintah dari Kodam IV Sriwijaya Anna diminta untuk menciptakan sebuah tari penyambutan yang baru. Jiwa berkesenian yang dimiliki Anna sebagai putri daerah setempat menjadikan proses persiapan dalam menciptakan tari Tepak Keraton menjadi semakin sempurna.

Dengan berkembangnya ide, tersedianya sarana prasarana dalam berkesenian serta tuntutan kepuasan batin sebagai seorang koregrafer yang harus menciptakan tari yang mampu diterima masyarakat menjadi bagian pada tahap persiapan yang dilakukan Anna dalam proses penciptaan tari Tepak Keraton.

\section{Tahap Inkubasi}

Tahap inkubasi merupakan tahap penyimpanan ide dan merenungkannya. Dalam proses ini Anna dalam gejolak pemikirannya berusaha mengamati fenomena disekitarnya yang kemudian dicerminkan dengan ide kreatifnya. Dengan kata lain pada tahap ini Anna berusaha sebisa mungkin menciptakan sesuatu yang baru dan tidak meniru apa yang sudah ada. Sebagai contoh, dari segi busana yang seharusnya Anna dapat menggunakan pakaian dodotan sebagai busana tari Tepak Keraton, namun Anna meninjau ulang bahwa pakaian dodotan merupakan hasil peninggalan kebudayaan agama Hindu dan Budha, karena tarian ini mengusung sosial religi keislaman, maka Anna memilih busana pak sangkong ${ }^{3}$ sebagai busana yang tepat untuk melengkapi karya tari ini. Begitu pula halnya dengan koreografi, musik iringan dan pola lantainya, Anna benar-bnar mempersiapkan segala hal tersbut agar menjadi sebuah sajian yang utuh dan diakui kebaruannya.

\section{Tahap Pencerahan}

Tahap pencerahan artinya seorang seniman kreatif dalam mencari ide mulai membayangkan dan memikirkan kemungkinankemungkinan yang menyimpang dari kelaziman. Biasanya ide kreatif akan muncul dengan menyilangkan pandangan fungsional

\footnotetext{
${ }^{3}$ Pak Sangkong merupakan salah satu pakaian adat masyarakat Kota Palembang yang terdiri dari baju kurung dan kain songket yang menutup seluruh bagian aurat perempuan.
} 
dengan pandangan yang non fungsional dan akan lahir pemikiran yang baru. Tujuan dari pada tahap pencerahan ini semata-mata untuk menghindari pikiran statis.

Dalam fase ini Anna sebagai penata tari muda pada saat itu banyak mendapatkan ide dan inspirasi serta gagasan baru mengenai tari sambut yang akan ia ciptakan, namun tidak semua ide dan gagasan tersebut dapat serta merta dituangkannya dalam karyanya. Anna harus juga memperhatikan perspektif masyarakat yang telah terpatri dan terbingkai jauh sebelumnya mengenal konsep ketradisian. Oleh karena itu Anna memilah dan menelaah ulang dari setiap ide gagasannya, mana-mana yang dapat ia kekalkan dalam karyanya dan mana yang tidak, semua itu tetap harus dilandaskan dengan asumsi dan argumen serta perspektif yang kuat dan rasional.

Sebagai contoh, dari segi kesejarahan, Anna meninggalkan pengaruh Hindhu-Budha yang telah melekat kuat pada tari penyambutan sebelumnya. Kemudian Anna terinspirasi dari kejayaan kesultanan Palembang Darussalam yang pernah ada pada masa lampau. Ide ini dipertahankan bukan tanpa perspektif yang kuat, mengingat saat itu mayoritas penduduk Kota Palembang adalah muslim dan dahulu pernah berjaya Kesultanan Islam di Kota Palembang, sehingga Anna dengan yakin menyuguhkan kebaruan dalam karyanya dari segi sosio religi.

\section{Tahap Pelaksanaan}

Setelah melalui dan meyakini ketiga tahapan sebelumnya, pada tahapan ini Anna memulai pengkaryaanya. Hal yang pertama dilakukan Anna adalah menata koreografinya. Anna menata gerak yang lebih variatif dan berusaha lari dari bingkai Hinduisme dan Budhiisme yang selama ini telah membingkai profil tari sambut Sumatera Selatan pada ummnya. Dengan meyakini hal tersebt Anna membuat stigma baru bahwa unsur local genius kepalembangan dan keislaman dapat menjadi bingkai baru dalam aliran karyanya. Hal ini dapat dilihat dari nama ragam gerak yang mengangkat karakteristik kepalembangan dan filosofi gerak yang berlandaskan keislaman. Setelah itu Anna Menentukan Jumlah penari baku pada tari Tepak Keraton yaitu berjumlah 7 orang penari. Hal ini dipertahankan karena Anna memiliki argumen dan asumsi yang kuat dalam karyanya, jumlah penari yang hanya 7 orang penari tersebut dikarenakan Anna ingin menggambarkan sosok 7 orang putri dan ratu yang namanya pernah menjadi legenda dan telah menjadi keyakinan bersama masyarakat Kota Palembang Asli, mereka adalah Ratu Sinuhun, Putri Kembang Dadar, Putri Dayang Merindu, Putri Campa, Ratu Bagus Kuning, Ratu Mariam dan Putri Siti Fatimah (wawancara Anna, November 2016). Kemudian Anna menggarap musik pengiring karyanya yang juga baru, musik tersebut berjudul Enam Saudara. Akan tetapi tidak meninggalkan identitas kemelayuan Kota Palembang yang notabene nya merupakan 
Kota Melayu Islam. Tak hanya sebatas itu, Anna pun mengembangkan pola lantai yang dahulunya telah diakui oleh masyarakat tradisi bahwa pola lantai tari sambut di Sumatera Selatan umumnya statis. Dengan kepiawaiannya Anna mengubah pola Lantai menjadi Dinamis. Terlebih lagi suasana kedinamisan tersebut dengan jelas tergambarkan dari gerak silat yang ditampilkan pada pertengahan sajian Tari Tepak Keraton yang juga dilakukan oleh penari perempuan. Tahap pembentukan terakhir yaitu dari busana. Dengan mengangkat keislamannya Anna memeilih pakaian adat Pak Sangkong sebagai busana Tari Tepak Keraton, karena pakaian Pak Sangkong merupakan salah satu pakaian adat Kota Palembang yang terdiri dari baju kurung dan kain songket. Dengan kata lain, pakaian PakSangkong ini dapat menutup seluruh bagian tubuh penari kecuali pada bagian wajah, tangan dan kaki. Hal ini sesuai dengan syariat agama Islam yang menganjurkan umat Islam perempuan yang sudah akhil baligh ${ }^{4}$ untuk menutup auratnya. Berdasarkan wawancara bersama mirza, November 2016.

Aesan 5 Pak Sangkong menggunakan baju kurung yang diciptakan oleh Ratu Sinuhun, putri dari Ketemenggung Manco Negaro Maulana Padlullah dan Nyai Gede Ing Pembayun. Ratu Sinuhun adalah permaisuri dari Gede

4 Akil Baligh merupakan keadaan kedewasaan yang dialami oleh setiap manusia, umumnya dicapai pada usia 14-15 tahun dalam hukum Islam.

5 Aesan merupakan sebuah istilah dalam bahasa palembang lama yang artinya perhiasan.
Sido Ing Kemeyau yang memerintah Kota Palembang pada tahun 19601965 sebagai Raja Palembang Darussalam ke-7 (wawancara Mirza, November 2016).

Pada tahap pelaksanaan ini Anna dibantu beberapa teman-temannya dalam menyajikan tari Tepak Keraton untuk pertama kalinya yanng terdiri dari 7 orang penari, 1 orang pesilat, 1 orang penyanyi, 1 orang pemegang payung dan 2 orang pemegang tombak, mereka adalah Anna Kumari, Masayu Indrawati,R.A Yulia Zahara, R.A. Agustani, R.A. Masnila, Nurjannah, R.A. Zaleha Hamid Ternate, Masayu Yati Karim, Atira Timur Raya, R.A. Aisah Hamid Ternate, Ristama, dan R.A.Nuraisyah.

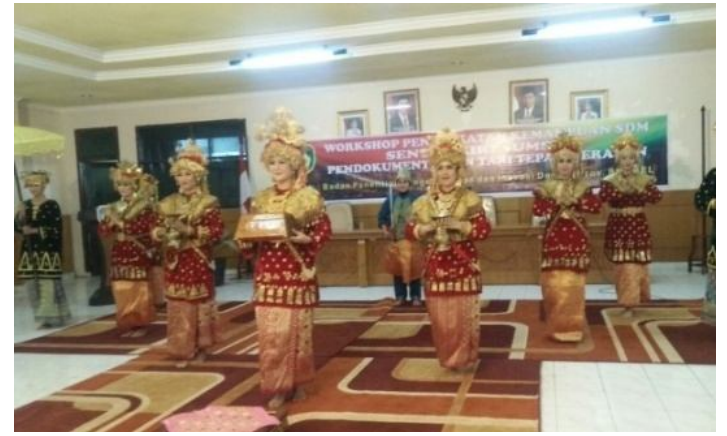

Gambar 1: Bentuk Sajian Tari Tepak Keraton

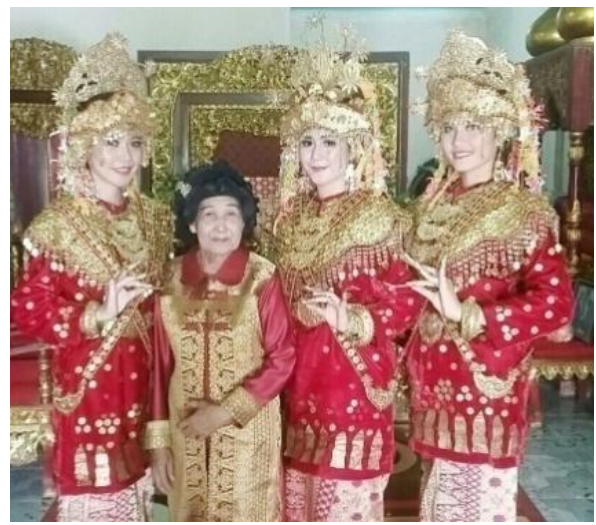

Gambar 2: Anna Kumari Bersama Beberapa Penari Tepak Keraton 


\section{SIMPULAN}

Anna Kumari merupakan seniman tari di Kota Palembang yang memiliki perhatian besar terhadap pelestarian seni tradisi. Dilatarbelakangi oleh pengalamannya dalam berkesenian Anna Menciptakan karya tari Tepak Keraton Sebagai tari Penyambutan Pangdam IV Sriwijaya pada saat itu. Tari Tepak Keraton Merupakan salah satu tari penyambutan yang mewarnai tari sambut di Kota Palembang. Diciptakan pada tahun 1966, tari Tepak Keraton mengusung tema keislaman. Walau telah berusia lebih kurang 50 tahun, tari ini tetap mampu bertahan ditengah maraknya perkembangan seni pertunjukan di Kota Palembang. Kreativitas Anna Kumari dalam tari Tepak Keraton berawal dari ide gagasan kebaruan, di mana tari sambut yang pernah ada sebelumnya yaitu tari Gending Sriwijaya merupakan tari penyambutan yang bernuansa Hindu-Budha, maka Anna menciptakan tari ini dengan nuansa keislaman, namun tetap tidak melepas nilai-nilai tradisi setempat yang menjadi ruh daripada tari tradisi di Sumatera Selatan. Dengan pengalamannya sebagai seniman dan budayawan serta kepenariannya sebagai seorang penari dan guru tari, Anna menciptakan tari melalui proses kreativitas dengan empat tahapan, yaitu tahap persiapan, inkubasi, pencerahan, dan pelaksanaan, hingga terciptalah tari sambut Tepak Keraton.

\section{DAFTAR PUSTAKA}

Andrianto, Tuhana Taufiq. 2013. Cara Cerdas Melejitkan IQ Kreatif Anak. Jogjakarta: Kata Hati. Arikunto, Suharsimi. 2010. Prosedur Penelitian Suatu Pendekatan Praktik. Yogyakarta. Rineka Cipta Sugiono. 2009. Metode Penelitian Kuantitatif Kualitatif dan R\&D. Bandung. Alfabeta. 2010. Metode Penelitian Pendidikan. Bandung : Alfabeta

Sumardjo Jacob. 2000. Filsafat Seni, Bandung: ITB Press.

Munandar, Utami. 2002. Anak Unggul Berotak Prima. Jakarta. PT. Gramedia.

Nara Sumber :

1. Anna Kumari, Pencipta Tari Tepak Keraton, 72 Tahun

2. Mirza Indah Dewi, Pelestari Tari Tepak Keraton , 40 Tahun 


\section{KETENTUAN PENULISAN ARTIKEL JURNAL SITAKARA}

1. Naskah berbahasa Indonesia bertemakan Seni Budaya yang meliputi hasil penelitian pengajaran seni budaya, cabang seni, dan kebudayaan.

2. Naskah harus asli dan belum pernah dimuat dalam media lain. Naskah dapat berupa hasil penelitian perorangan atau kelompok. Naskah ditulis dengan cara-cara yang sesuai dengan ketentuan penulisan artikel ilmiah menggunakan bahasa Indonesia yang baku, berupa ketikan, beserta soft line dalam CD-RW atau dengan mengirimkan email pada redaksi Jurnal Sitakara dengan alamat email: jurnalsitakarasendratasik@yahoo.com, spasi 1,5 jenis huruf Arrial Narrow ukuran 12, dengan panjang naskah antara 8-15 halaman pada kertas A4.

3. Artikel hasil penelitian memuat:

JUDUL

NAMA PENULIS

ABSTRAK

\section{A. PENDAHULUAN}

B. METODE PENELITIAN

C. HASIL DAN PEMBAHASAN

D. SIMPULAN

4. Artikel kajian konseptual memuat JUDUL

NAMA PENULIS

ABSTRAK

PENDAHULUAN

SUB JUDUL

SIMPULAN

DAFTAR PUSTAKA

\section{: XXX (HURUF KAPITAL)}

: (disertai jabatan dan institusi)

: (Bahasa Indonesia yang memuat 100- 150 kata diikuti kata kunci, dengan jenis huruf Arrial Narrow dan ukuran huruf 11 serta dicetak tebal).

: (Memuat latar belakang masalah, tinjauan pustaka Secara ringkas, masalah dan tujuan penelitian).

: (Berisi simpulan)

: XXX (HURUF KAPITAL)

: (disertai jabatan dan institusi)

: (Bahasa Indonesia yang memuat 100- 150 kata diikuti kata kunci, dengan jenis huruf Arrial Narrow dan ukuran huruf 11 serta dicetak miring)

: (Memuat latar belakang masalah, tinjauan pustaka secara ringkas, masalah penelitian dan tujuan penelitian)

: Sesuai dengan kebutuhan (tanpa numbering)

: (Berisi simpulan dan saran)

: (Berisi pustaka yang dirujuk dalam uraian naskah) 
5. Referensi sumber dalam teks artikel ditulis dengan menggunakan side note, contoh: (Jalalluddin, 1991:79); (Taufik, 2005;350); (Hamid dan Madjid, 2011:43). Sementara penulisan daftar pustaka disusun dengan ketentuan. Nama Pengarang. Tahun Terbit. Judul (dicetak miring). Kota Terbit: Nama Penerbit. Contoh: Koentjaraningrat. 2010. Manusia dan Kebudayaan Di Indonesia. Jakarta: Djambatan.

Daftar pustaka hanya memuat pustaka/sumber yang dirujuk dalam uraian dan disusun menurut abjad, tanpa nomor urut.

6. Naskah yang dimuat akan disunting kembali oleh redaksi tanpa mengubah isinya.

7. Naskah yang ditolak (tidak bisa dimuat) akan dikirim kembali ke penulis dengan pemberitahuan tertulis dari redaksi atau alamat email.

8. Penulis yang naskahnya dimuat akan mendapatkan 1 (satu) majalah nomor yang bersangkutan.

9. Contact Person: Treny (085357344704) dan Mainur (081373165553). 